\title{
PENDAMPINGAN APLIKASI BUKU BAHASA INGGRIS PRAKTIS BAGI PEDAGANG SOUVENIER DI PASAR SENI TAMAN NARMADA
}

\author{
Arafiq $\left.{ }^{*}\right)$, Nurrachman Hanafi, Muhammad Husni M., Syahdan, Kamaluddin Yusra \\ Fakultas Keguruan dan IImu Pendidikan Universitas Mataram \\ Jl. Majapahit 62, Mataram 83125, Lombok - Indonesia \\ *alamat korespondendi: arafiq@unram.ac.id
}

\begin{abstract}
ABSTRAK
Taman Narmada merupakan salah satu obyek wisata yang berada di Kecamatan Narmada Kabupaten Lombok Barat. Taman Narmada menjadi salah satu andalan wisata bagi Kabupaten Lombok Barat, Seperti halnya obyek-obyek wista lainnya, Taman Narmada menjadi destinasi yang lumayan sering dikunjungi oleh wisatawan lokal maupun mancanenagara. Dengan kehadiran wisatawan tersebut, masyarakat dapat membuka lapangan usaha yang baru, misalnya membuka usaha yang menawarkan kuliner dan juga souvenier. Oleh karana itu masyarakat harus diberdayakan untuk dapat memberikan pelayanan yang baik dan berkualitas kepada para wisatawan sehingga keberlangsungan hidup mereka dan keluarganya kedepan dapat terjaga dan ditingkatkan. Kegiatan pengabdian kepada masayarat ini bertujuan untuk memberikan Pendampingan terhadap aplikasi buku praktis Bahasa Inggris bagi pedagang souvenier di Pasar Seni Taman Narmada, Kecamatan Narmada Kabupaten Lombok Barat yang mencakupi percakapan-percakapan tentang welcome tourists, introducing to tours, explaining safety rules, dan etiquette, showing places of interest. aspek kosa kata tour guide vocabulary, dan contoh rekaman tour guide speech. Kegiatan pengabdian kepada masyarakat ini dilaksakan dengan metode partisipatif sehingga diharapkan semua peserta aktif terlibat dalam kegiatan pelatihan, mulai dari perencanaan, pelaksanaan, sampai pada tahap evaluasi. Hasil kegiatan ini sangat bermanfaat bagi masyarakat mitra karena dengan kegiatan tersebut mereka dapat mengetahui, mempraktekkan pengalaman selama kegiatan berlangsung dalam memperkenalkan souvenier, mengatakan harga dan transakasi, menunjukkan dan menjelaskan tempat-tempat yang menarik di taman narmada.
\end{abstract}

Kata kunci : bahasa inggris, buku praktis, pedagang souvenier, taman narmada 


\section{PENDAHULUAN}

Narmada merupakan salah satu kecamatan yang termasuk didalam wilayah pengembangan sektor pariwisata Kabupaten Lombok Barat (Anonim, 2013). Seperti halnya daerah pengembangan sektor pariwisata lainnya di Kabupaten Lombok Barat khususnya dan di pulau Lombok pada umumnya, Narmada menjadi destinasi penting yang sering dikunjungi oleh bagi wisatawan lokal maupun mancanenagara. Dengan modal keindahan alamnya yang masih asri, seperti area persawahan yang masih cukup luas, menjadikan Narmada betul-betul sebagai destinasi alternatif yang menjadi daya tarik yang menawarkan kepuasan yang lengkap bagi para wisatawan. Demikian juga dengan tamannya yang menawarkan tidak hanya keindahan dan keasrian, tetapi juga sejarah yang sangat menarik dari taman dan tempattempat yang ada di lamannya. Tidaklah keliru jika Pemerintah Kabupaten Lombok Barat menjadikan Narmada sebagai wilayah pengembangan sektor pariwisata andalan selain Senggigi yang sudah dikenal cukup lama.
Walaupun tidak sepopuler Senggigi (Aziz, 2015), kegiatan pariwisata di wilayah Narmada terlihat cukup bagus. Hal tersebut juga secara langsung berimbas pada peningkatan ekonomi masyarakat setempat. Keberadaan wisatawan di tempat tersebut tentu saja mendatangkan keuntungan bagi masyarakat setempat, karena dengan kehadiran wisatawan tersebut, masyarakat dapat membuka lapangan usaha yang baru untuk meningkatkan taraf hidup keluarga, misalnya membuka usaha yang menawarkan souvenir, oleh-oleh khas daerah, makanan-makanan khas daerah, serta jasa pemanduan (guide) kepada wisatawan untuk kunjungan ke spot-spot yang berada di kawasan Taman Narmada (Anonim, 2016).

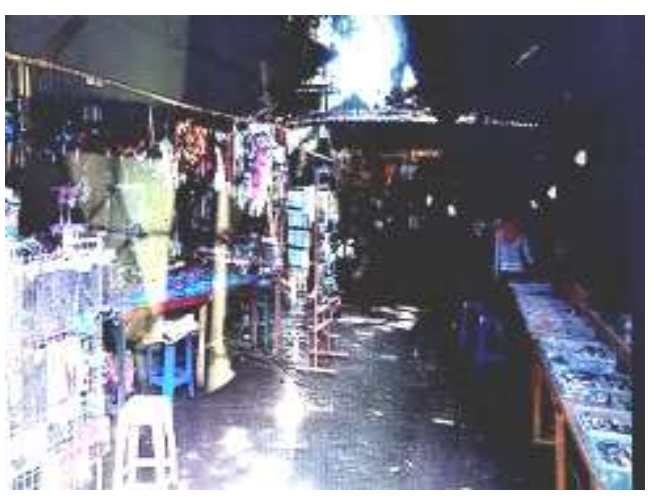

Gambar 1. Aktivitas

Pedagang Souvener di Pasar Seni Taman Narmada

Keberdaan masyarakat tersebut tentu harus terus 
diberdayakan untuk dapat memberikan pelayanan yang baik dan berkualitas kepada para wisatawan sehingga keberlangsungan hidup mereka dan keluarganya kedepan terus meningkat. Pemerintah dan lembaga-lembaga lain terkait harus menaruh perhatian yang cukup terhadap pemberdayaan masyarakat, misalnya melalui pelatihan, atau kegiatan pengembangkan SDM lainnya.

Berdasarkan dan diskusi ringan yang dilakukan terhadap beberapa pelaku wisata, khsusnya pedagang souvenir di Pasar Seni Taman Narmada, maka diperoleh beberapa permasahalan, yang salah satunya adalah masalah keterampilan berbahasa asing (Inggris). Menurut penuturan salah seorang pedagang souvenier, permasalahan Bahasa Inggris merupakan sesuatu yang krusial yang sering kali membuat beberapa di antara pedagang souvenier tidak percaya diri dalam berkomunikasi dengan para wisatawan. Terkadang permasalahan ini mengharuskan mereka menaikkan harga beberapa produk karena harus memberikan sejumlah uang kepada guide yang membawa tamu-tamu tersebut. Hal ini tentu menyebabkan barang mereka tidak kompetitif dari segi tarif. Selain itu, perbedaan nilai tukar Rupiah (Rp) dengan mata uang asing, khususnya US Dollar (US\$) juga menjadikan barang yang mereka jual terlihat mahal.

Dengan memperhatikan permasalahan tersebut, maka kegiatan pengabdian kepada masyarakat dengan judul "Pendampingan aplikasi buku praktis Bahasa Inggris bagi pedagang souvenier di pasar seni taman narmada Lombok Barat" dianggap penting dan relevan untuk dijadikan sebagai selaha satu kegiatan untuk meningkatkan dan memberdayakan masyarakat Narmada.

Adapun target luaran dari kegiatan pengabdian kepada masyarakat ini adalah Buku Saku Bahasa Inggris untuk pedagang souvenier untuk melengkapi buku bahasa inggris praktis bagi pelaku pariwisata yang ada sebelumnya, yang berisikan tentang welcome tourists, introducing to tours, tour guide 
vocabulary, dan percakapanpercakapan tentang explaining safety, rules, etiquette, showing places of interest, dan sample tour guide speech (Arafiq dkk, 2016).

\section{METODE KEGIATAN}

Pendekatan/Metode yang digunakan dalam kegiatan ini adalah pendekatan/metode partisipatif. Pendekatan/metode ini berorientasi pada upaya peran serta sasaran secara langsung dalam berbagai proses dan tahap pelaksanaan kegiatan, mulai dari perencanaan, pelaksanaan, sampai pada evaluasi kegiatan. Sasaran tidak hanya bertindak sebagai objek kegitan, tetapi juga sebagai pelaku kegiatan. Sementara itu, Tim Pelaksana hanya bertindak sebagai fasilitator dan motivator.

Konsfirmasi rencana kegiatan disampaikan kepada sasaran, sekaligus membicakaran tentang tempat, waktu, serta hal-hal teknis lainnya supaya terbangun sinergisitas antara Tim Pelaksana dengan sasaran.

Kegiatan pelatihan dilakukan dengan teknik diskusi dan dilanjutkan dengan pendalaman materi melalui praktek (simulasi) di dalam kelas dengan pendampingan yang dilakukan oleh Tim Pelaksana. Materi pelatihan dalam kegiatan ini adalah welcome tourists, introducing to tours, tour guide vocabulary, dan percakapanpercakapan tentang explaining safety, rules, etiquette, showing places of interest, dan sample tour guide speech.

Evaluasi terhadap capaian target kegiatan dilakukan dengan menilai ketercapaian tujuan kegiatan pengabdian kepada masyarakat. Teknik evaluasi dilakukan dengan pengamatan dan tanya jawab langsung kepada perseta pelatihan (pedagang souvenier).

\section{HASIL DAN PEMBAHASAN}

Kegiatan pengabdian kepada masyarakat ini diawali dengan pertemuan yang dilaksanakan pada 29 Oktober 2018 bertujuan untuk membicarakan hal-hal teknis terkait pelakanaan kegiatan, seperti, waktu, tempat, dan pola pelaksanaan. Koordinasi kegiatan ini dihadiri oleh Pihak Pengelola Taman Narmada (Manajer) dan beberapa perwakilan pedagang souvenier di pasar seni taman narmada. Hasil pertemuan ini 
disepakati bahwa kegiatan kegiatan tahap ini berlangsung

dilaksanakan pada 5 Nopember 2018 yang bertempat di Bale Gede, salah satu bagunan aula yang berada ti dalam kawasan Taman Narmada.

Berdasarkan permasahalan yang ditemukan, maka solusi yang ditawarkan untuk mengatasi salah satu masalah yang dihadapi, yakni keterampilan komunikasi Bahasa Inggris adalah memberikan pendampingan penggunaan buku Bahasa Inggris Praktis kepada para pedagang souvenier di pasar seni taman narmada, Kecamatan Narmada, Lombok Barat.

Pendampingan Aplikasi Buku Bahasa Inggris Praktis ini dilakukan dengan pendekatan komunikatif klasikal. Kegiatan diawali dengan memaparkan topik-topik dari Buku Percakapan Bahasa Inggris Praktis. Kegiatan kemudian dilanjutkan dengan latihan komunikatif sehingga setiap peserta diminta untuk menggunakan dan sekaligus mempraktekkan ungkapan-ungkapan Bahasa Inggris yang telah diberikan. Sebelum topik tertentu dikuasai, peserta belum diberikan topik yang baru. Selama anggota tim yang lain memberikan bimbingan kepada peserta yang mengalami kesulitan dalam mengikuti pemaparan klasikal.

Tahap selanjutnya adalah tahap pendalaman. Pada tahap ini, peserta diberikan bimbingan khusus secara intensif dalam mempraktekkan semua topik atau materi yang diberikan. Peserta dibagi dalam 2 orang (sepasang) untuk melakukan unjuk kerja terhadap topik-topik yang telah dipejari dengan menggunakan metode pairwork (Anonim, 2001). Tim memfasilitasai beberapa pasangan dengan memberikan bimbingan dalam memaknai ungkapan-ungkapan, mengucapkan kata-kata, serta intonasi ketika melakukan praktek percakapan. Butuh waktu yang lumayan lama bagi tim untuk memastikan bahwa semua peserta dapat dengan mudah untuk melakukan tahapan pendalaman ini. Namun demikian tahapan ini berlangsung dengan baik dalam suasana yang santai dan bebas sehingga peserta tidak merasa tertekan dan malu dalam melakukan instruksi yang diberikan oleh tim. 


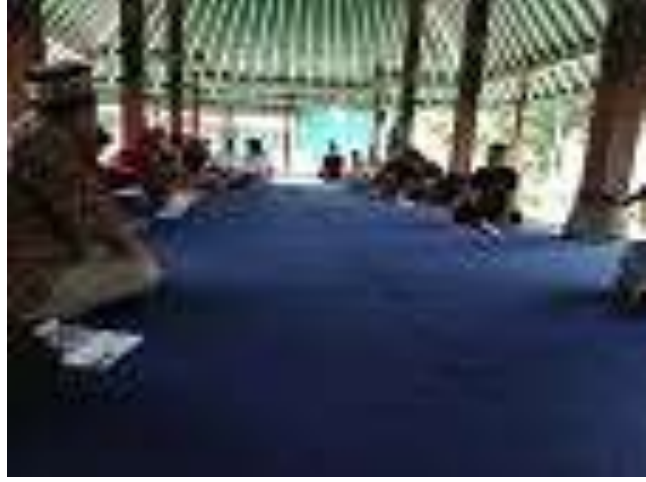

Gambar 2. Kegiatan Pendampingan klasikal

Evaluasi dilakukan dengan cara observasi (pengamatan) terhadap penampilan/keterampilan peserta dalam melakukan percakapan terhadap semua topik yang diberikan selama pelatihan. Berdasarkan hasil observasi tersebut, ditemukan bahwa secara umum, kamampuan perserta dalam berskomunikasi menggunakan Bahasa Inggris, khususnya topik-topik welcoming tourists, introducing to tours, tour guide vocabulary, cukup bagus, lebih-lebih setelah mendapatkan pembimbingan aplikasi buku praktis tersebut. Namun ada beberapa topik yang masih perlu pembimbingan lebih, yakni explaining safety rules, etiquette, showing places of interest, dan sample tour guide speech.

Hal lain yang diperoleh dari hasil pengamatan selama kegiatan pengabdian kepada masyarakat ini adalah keseriusan dan ketekunan peserta selama mengikuti kegiatan yang sangat bagus. Hal ini menunjukkan bahwa peserta sudah mulai memiliki sikap positif terhadap Bahasa Inggris. Sikap positif ini merupakan modal utama untuk dapat memotifasi peserta didik untuk terus menerus belajar mengembangkan dan meningkatkan kemampuan Bahasa Inggris mereka. Dengan dimilikinya sikap positif terhadap Bahasa Inggris, diharapkan timbul pemikirian dari dalam diri masyarakat betapa Bahasa Inggris itu adalah sesuatu yang penting dalam menunjang usaha masyarakat. Ketika sesorang yang belajar Bahasa Inggris menganggap Bahasa Inggris sebagai suatu kebutuhan, maka kendala belajar tidak menjadi halangan untuk menjadi pembelajar yang sukses (Arafiq dkk, 2016).

\section{KESIMPULAN DAN SARAN}

\section{Kesimpulan}

$$
\text { Kegiatan pendampingan }
$$

aplikasi buku percakapan Bahasa Inggris praktis bagi pedagang souvenier di Narmada Kabupaten Lombok Barat telah dilaksanakan 
dengan baik. Persoalan yang dihadapi oleh mitra (pedagang souvenier) di Narmada yang berkaitan dengan keterampilan berkomunikasi dengan Bahasa Inggris secara umum sudah teratasi. Semua peserta pelatihan sudah mampu, berani, dan memiliki kepercayaan diri yang cukup untuk berkomunikasi dengan menggunakan Bahasa Inggris dalam menghadapi wisatwan mancanegara. Namum demikian kedepan, diperlukan program yang berkelanjutan dengan cakupan kegiatan yang lebih luas sehingga keterampilan yang dimiliki saat ini dapat terus dimiliki dan ditingkatkan lagi.

\section{Saran}

Kegiatan pengabdian kepada masyarakat dalam bentuk pelatihan, pendampingan dan pembimbingan Bahasa Inggris komunikasi yang intensif bagi pengelola, pedagang souvenir, dan pihak-pihak lain yang berkecimpung dalam aktivitas pariwisata di Taman Narmada, perlu dilakukan dengan melibatkan sasaran yang lebih luas, mulai dari kantor depan (ticketing), obyek-obyek wisata, pasar seni, dan tempat parkir dalam waktu yang cukup lama ehingga betulbetul dapat membawa manfaat bagi sasaran. Disamping itu, perlu dilakukan pendampingan secara terus-menerus guna mendukung pembangunan sektor pariwisata di Taman Narmada.

\section{UCAPAN TERIMAKASIH}

Terimakasih kepada Lembaga Penelitian dan Pengabdian kepada Masyarakat Universitas Mataram yang telah mendanai kegiatan pengabdian ini. Terimakasih yang sama juga disampiakan kepada Dekan Fakultas Keguruan dan Ilmu Pendidikan Universitas Mataram yang telah memberikan izin kepada seluruh tim untuk melaksanakan kegiatan ini. Terimakasih juga disampikan kepada pihak Manajemer Taman Narmada beserta personilnya yang telah memfasilitasi tempat dan fasilitasfasilitas yang lain sehingga kegiatan ini dapat berjalan dengan baik. Terimakasih juga disampiakan kepada para pedagang souvenier di pasar seni taman narmada yang telah ikhlas mengikuti tahapan demi tahapan kegiatan ini sehingga target kegiatan ini dapat tercapai dengan baik. 
Terkahir, terimasaih kepada segenap tim yang telah bekerja keras, merancang kegiatan, mengumpulkan materi, melaksanakan, mengevaluasi, hingga menyusun laporan kegiatan pengabdian tepat pada waktunya.

\section{DAFTAR PUSTAKA}

Anonim, 2001. Practical English for Tour Guide. Yayasan Kerya Wisata Mataram, Akademi Pariwisata Mataram.

Anonim, 2013. Profil Potensi Pariwisata Lombok Barat. http://dinaspariwisatalombok barat.blogspot.co.id/2012/03/ profil-pariw.isata-lombokbarat.html: Diakses 14 Maret 2017.
Anonim, 2016. Peta Kelurahan/ Narmada Lombok Barat. http://peta-jalan.com/Narmada-kab-lombok-barat/: Diakses 14 Maret 2017.

Arafiq, Mu'adz, H.M., \& Ahmadi, N. 2016. Pelatihan Bahasa Inggris Bagi Pengelola Wisata Desa di Desa Meninting Lombok Barat. Laporan Pengabdian Kepada Masyarakat Sumber Dana PNBP Universitas Mataram Tahun 2016.

Aziz, A. D. 2015. Aplikasi Buku Saku Sebagai Panduan Percakapan Bahasa Inggris Bagi Pedagan Asongan Di kawasan Wisata Lombok. Laporan Akhir Pengabdian Kepada Masyarakat Sumber Dana BOPTN Universitas Mataram. 